\title{
RELATIONSHIP OF PREMATURE RUPTURE OF MEMBRANES (PROM) WITH NEONATORY ASPHYSIA IN SANTA ELISABETH HOSPITAL BATAM CITY
}

\author{
Roni Aldiano ${ }^{1}$, Fitta Deskawati ${ }^{2}$ \\ ronialdiano@ univbatam.ac.id ${ }^{1}$, fittadeskawaty@univbatam.ac.id ${ }^{2}$ \\ Professional Doctor Study Program, Faculty of Medicine, Batam University ${ }^{1}$ \\ Medical Education Study Program, Faculty of Medicine, University of Batam ${ }^{2}$ \\ Jl. Abulyatama No 5 - Kota Batam
}

\begin{abstract}
Background : The high rate of infant mortality is caused by many factors, including neonatal asphyxia and premature rupture of membranes. KPD followed by infection can increase perinatal morbidity and mortality. Asphyxia is a newborn emergency in the form of respiratory depression that continues, causing various complications. This study aims to determine the relationship between premature rupture of membranes and Asphyxia Neonatorum.

Method: The research method used was an analytic survey with a cross sectional approach. Conducted at the ST Hospital. Elisabet, the study was conducted for 6 months, the population in this study were all patients in the delivery room with term delivery at Santa Elisabeth Hospital, Batam City from January to December as many as 1,018 people. The sample in this study was 91 people. The sampling technique was carried out by systematic random sampling technique with research instruments using checklists. Data analysis using Chi square.
\end{abstract}

Result :The results of the study with a sample of 91 in 32 mothers with KPD, showed 20 neonates (62.5\%) were not asphyxia and 12 neonates $(37.5 \%)$ had asphyxia. Meanwhile, 59 non-KPD mothers whose babies were not asphyxiated were 53 neonates $(89.8 \%)$ and 6 neonates had asphyxia $(10.2 \%)$. The analysis results obtained $\mathrm{p}=0.004(<0.05)$.

Conclusion : The conclusion is that there is a relationship between PROM and the incidence of neonatal asphyxia at term delivery at Santa Elisabeth Hospital, Batam City. Research suggestion that efforts to reduce the incidence of KPD can be increased

Key words: Premature rupture of membranes (PROM), Asphyxia Neonatorum

\section{PRELIMINARY}

One of the indicators of optimal health status is the Maternal Mortality Rate (MMR) and the Infant Mortality Rate (IMR). Pregnancy is a physiological condition, which cannot be ignored because every pregnancy carries risks, where these risks will have an impact on the health of pregnant women and the fetus.

During pregnancy, premature rupture of membranes sometimes occurs or what is often called premature rupture of membranes (KPD). Normally the amniotic membrane will break after there are signs of labor, but in some conditions the membranes rupture early before there are signs of labor. Premature rupture of membranes is an important problem in obstetrics related to the complication of preterm birth and the occurrence of infection to sepsis which increases perinatal morbidity and mortality and causes maternal infection (Prawirohardjo, 2013). This requires fast and precise handling to prevent intrauterine infections that can threaten the safety of the mother and baby

One of the factors that can cause maternal infection is premature rupture of membranes which is an important problem in obstetrics and is the biggest cause of preterm labor with various consequences The incidence of premature rupture of membranes occurs in 6$20 \%$ of pregnancies (Hariadi, 2004). In Indonesia, labor which is preceded by premature rupture of membranes is $\pm 10 \%$. (Anonymous, 2006). The cause of premature 
rupture of membranes is still not known with certainty but Taylor et al. Have investigated this and stated that predisposing factors for premature rupture of membranes are amniotic disorders, infection, multiple para, malposition, cephalopelvic disproportion and incompetent cervix. The occurrence of premature rupture of the membranes causes various complications. The rupture of the membranes causes a direct connection between the outside world and the inside of the uterus, thus facilitating the occurrence of maternal infections. In addition, other complications that can be caused by the incidence of premature rupture of membranes are preterm labor and compression of the talipusat. With the compression of the umbilical cord can cause hypoxia in the fetus so that asphyxia can occur in newborns (Scoot, 2002: 177)

According to the World Health Organization (WHO) the incidence of PROM in 2013 was $50 \%-60 \%$ in pregnancy. Whereas in Indonesia in 2013 as much as $35 \%$ of pregnancies. The highest incidence of KPD occurred in term pregnancy, namely $95 \%$, while in preterm pregnancy was slightly $34 \%$ (Ministry of Health, Republic of Indonesia, 2013)

According to (Prawirohardjo, 2007: 709), asphyxia is the failure of a baby to breathe and maintain it, if late it can cause death, and lifelong disabilities such as blindness, deafness, and brain defects. Asphyxia neonatorum is the first cause of neonatal death in developing countries in 2007 . namely $21.1 \%$, besides pneumonia and neonatal tetanus were $19.0 \%$ and $14.1 \%$, respectively. Reported neonatal deaths were neonatal asphyxia (33\%), prematurity (10\%), LBW (19\%). According to the WHO working group report, of the million infant deaths in the world, $48 \%$ are neonatal deaths, about $60 \%$ are deaths of infants aged $<7$ days, which are caused by perinatal disorders, one of which is asphyxia.

According to the World Health Organization (WHO), almost every year about $3 \%$ of the 120 million babies born have asphyxia, nearly 1 million of these babies later die. The causes of LBW mortality in Indonesia are low birth weight babies (29\%), asphyxia (27\%) infection, congenital abnormalities and others (44\%) (WHO, 2012). The infant mortality rate (IMR) in Lampung was 30 per 1000 births in 2013, while the 2015 MDGs target was 23 per 1000 births. The causes of infant mortality were among others caused by LBW by $33.1 \%$ and Asphyxia by 30.1 .

Premature rupture of membranes is a risk factor for the incidence of Asphyxia Neonatorum which has the highest percentage, namely $89.5 \%$ of 38 cases of asphyxia in newborns. The results of I Made Kardana's (2016) study stated that early rupture of membranes had a 10.61 times higher risk of asphyxia in However, the results of Muntari's (2011) study show different things, namely that there is no significant relationship between Dinidian rupture and the incidence of Asphyxia Neonatorum, $p=0.064$ where $p<0.05 .10$ This is an inconsistency in the results of research on the relationship between ruptured membranes and incidence. Asphyxia Neonatorum.

From the initial survey that was carried out at the Santa Elisabeth Hospital in Batam City, 1,018 pregnant women delivered at term from a total of 1,857 deliveries from January to December. Of the 1,018 deliveries, there were 80 mothers who experienced PROM

From the background problems above, the researcher is interested in taking a research title, namely the relationship of premature rupture of membranes with asphyxia neonatorum.

\section{RESEARCH PURPOSES}

This study aims to determine the relationship between premature rupture of membranes and neonatal asphyxia at ST Elisabet Hospital, Batm City.

\section{RESEARCH METHODS}

The research method used was an analytic survey with a cross sectional approach. Conducted at the ST Hospital. Elisabet, the study was conducted for 6 months, the population in this study were all patients in the delivery room with term delivery at Santa Elisabeth Hospital, Batam City from January to December as many as 1,018 people. The sample in this study was 91 people. The sampling technique was carried out by systematic random sampling technique. The instrument used in this 
study was a checklist sheet. The analysis was carried out in the form of Univariate and Bivariate using Chi square

\section{RESEARCH RESULT}

From the research that has been done at Santa Elisabeth Hospital, Batam City, by looking at the patient's medical record data, the results are obtained; as follows :

Of the 91 respondents at Santa Elisabeth Hospital, Batam City who experienced KPD 32 people (35.2\%) and those who did not experience KPD 59 people (64.8\%).

It is known that 91 respondents at Santa Elisabeth Hospital, Batam City, were 73 neonates without neonatal asphyxia (80.2\%) and 18 neonates $(19.8 \%)$ who experienced neonatal asphyxia.

Of the 91 respondents, out of 32 respondent mothers experiencing PROM, there were 20 neonates $(62.5 \%)$ who were not asphyxic and 12 neonates (37.5\%) who experienced asphyxia. Meanwhile, of the 59 mothers without PROM there were 53 neonates $(89.8 \%)$ who did not experience asphyxia and as many as 6 neonates (10.2\%) who experienced asphyxia. statistic 21 , so that the $p$ value $=0.004$. This figure shows a significant number because the $p$ value is smaller than the significance level (0.05). Thus it can be concluded that $\mathrm{H} 0$ is rejected and $\mathrm{H} 1$ is accepted or there is a relationship between KPD and the incidence of asphyxia neonatorum at Santa Elisabeth Hospital, Batam City.

\section{DISCUSSION}

\section{Premature rupture of membranes}

From the results of the study, 91 patients at Santa Elisabeth Hospital in Batam City who experienced PROM were 32 (35.2\%) and patients who did not experience PROM were 59 (64.8\%). These results indicate that the majority of mothers do not experience PROM at Santa Elisabeth Hospital, Batam City, however, there are still pregnant women who experience PROM. Many factors cause the occurrence of PROM. In the study, researchers looked at 32 patients who experienced PROM (Cephalopelvic Distporpotion) in $3 \mathrm{KPD}$ people, Oligohydramnios in 2 KPD people,
PEB (severe pre-eclampsia) in 1 PROM, and 26 people had no known cause of PROM.

CPD and PEB from the results of this study are probably the factors causing the occurrence of PROM. Meanwhile, Oligohydramnios is the result of PROM. And in 26 people whose cause was unknown, it was possible that there was an increase in proteolytic enzymes that were influenced from inside or outside the body which could weaken the strength of the amniotic membrane, resulting in PROM. Reinforced by the theory of Prawirohardjo (2010) which states that the cause of KPD is not clearly known or is still not clear, preventive efforts can be made only by suppressing infection.

Rupture of membranes in labor is generally caused by uterine contractions and repeated stretching. The membranes rupture because in certain areas there are biochemical changes that cause the inferior membranes to become brittle, not because the entire membranes are fragile. There is a balance between synthesis and degradation of the extracellular matrix. Changes in structure, cell number, and collagen catabolism cause collagen activity to change and cause the membranes to break (Prawirohardjo, 2013).

This research is in line with research conducted by Komsiyati (2015) which states that $31.2 \%$ of mothers giving birth at Ambarawa Hospital experience KPD. Meanwhile, from the observations on 32 mothers who experienced KPD in Santa Elisabeth Hospital, Batam City, there were more primiparous mothers with a total of 22 mothers $(68.75 \%)$ compared to multiparous mothers with a total of 10 mothers $(31.25 \%)$. In primiparous women experience labor for the first time. Based on the research data that has been presented, it shows that the incidence of PROM in maternal labor is not only influenced by parity, but other factors that cause PROM is stronger, namely polyhydramnios, CPD, PEB and others.

The results of this study are in line with the research of Firdhausya (2015) at Panembahan Senopati Bantul Hospital, which shows that PROM occurs mostly in primiparous mothers with a total of 13 people $(68.4 \%)$ compared to 6 people (31.6\%). This shows that 
women who are primiparous are more at risk of developing PROM than multiparous women because the state of the womb seems to have just been used to carry a fetus, so that adjustments to the womb of women are needed.

This study is also in line with Sepduwiana's (2011) research at RSUD Rokan Hulu which states that the majority of maternal mothers who experience PROM, mostly occur in 45 primiparous mothers (48.9\%), compared to 39 people $(42.40 \%)$ and the grandemultipara, namely 8 people $(8.70 \%)$.In primiparous the cause of premature rupture of membranes is because the first pregnancy is the toughest trial of the mother's reproductive ability (Nugroho, 2010).

However, the results of this study differ from Varney's (2004) theory that the predisposing factor for PROM is multiparous, the higher the parity of the mother, the less good the endometrium is, so that the strength of the uterine membrane is reduced. A theoretical discrepancy also occurs in the theory of Prawirohardjo (2010) which states that PROM is more often found in multiparous women than in nulliparous women. This is because the endometrium in women who have given birth will be more problematic than women who have just given birth once or have never given birth. When a woman who has had more than one pregnancy / childbirth has experienced a different placement of the placenta. This can cause the placenta in subsequent pregnancies to be prone to premature rupture of membranes.

According to the assumption of the researcher, that there is an agreement between the theory and the results studied. Because, the comparison of 1,018 pregnant women with term delivery, there were 80 mothers who experienced PROM. With a sample size of 91 mothers, 32 mothers who experienced PROM occurred more in primiparous mothers with a total of 22 mothers $(68.75 \%)$ compared to multiparous mothers with a total of 10 mothers $(31.25 \%)$.

\section{Asphyxia neonatorum}

Of the 91 samples in this study, there were 73 infants $(80.2 \%)$ who did not have asphyxia and $18(19.8 \%)$ who experienced asphyxia. A good APGAR with an APGAR value of $\geq 7$ can be called a vigorous baby (healthy baby) or not asphyxiated while a bad APGAR with an apgar value $<7$ is classified as neonatal asphyxia. Asphyxia neonatorum is a condition in which the baby cannot breathe spontaneously and regularly immediately after the baby is born (Prawirohardjo, 2013). Fetal hypoxia that causes neonatal asphyxia occurs due to disruption of gas exchange and transport of $\mathrm{O} 2$ from mother to fetus so that there is a disruption in $\mathrm{O} 2$ supply and in eliminating $\mathrm{CO} 2$. Changes in gas exchange and $\mathrm{O} 2$ transport during pregnancy and childbirth affect the oxygenation of body cells resulting in impaired cell function.

I Gede Manuaba (1998: 319) states that the sudden factors that can lead to neonatal asphyxia, one of which is the compression of the umbilical cord. Premature rupture of membranes can cause 3 things to happen, one of which is a maternal infection. Normal infection causes the formation of negative cells to form, then integrate and produce an endotoxin which then causes a strong vasospasmus in the veins, as a result of which there is fluid seepage from the vascular space to the extra-vascular space so that the circulating blood volume is insufficient. As a result, the blood flow of the maternal placenta is reduced, the $\mathrm{O} 2$ received by the fetus is also reduced, then hypoxyase is carried out so that when the baby is born, the baby is asphyxiated.

The results of this study showed that babies who did not experience asphyxia were slightly higher than the research conducted by Komsiyati (2015) at Ambarawa Hospital also showed that $67.6 \%$ of infants were not asphyxic while $32.4 \%$ of infants had asphyxia. Meanwhile, Firdhausya's research (2015) shows that as many as $65.5 \%$ of babies are not asphyxic, while $43.5 \%$ of babies have asphyxia. Babies born without asphyxia can reduce shortterm risks such as dysfunction of body organs such as brain, lung, liver, kidney, gastrointestinal tract, and blood system and long-term risks such as liver damage, bleeding and pulmonary edema (Manoe, 2008).

\section{Relationship between PROM and asphyxia Neonatorum}

Of the 91 respondents, out of 32 respondent mothers experiencing PROM, there were 20 
neonates $(62.5 \%)$ who were not asphyxic and 12 neonates (37.5\%) who experienced asphyxia. Meanwhile, of the 59 mothers without PROM there were 53 neonates $(89.8 \%)$ who did not experience asphyxia and as many as 6 neonates $(10.2 \%)$ who experienced asphyxia. statistic 21 , so that the $\mathrm{p}$ value $=$ 0.004 . This figure shows a significant number because the $\mathrm{p}$ value is smaller than the significance level $(\square)=5 \%(0.05)$. Thus it can be concluded that $\mathrm{H} 0$ is rejected and $\mathrm{H} 1$ is accepted or there is a relationship between KPD and the incidence of asphyxia neonatorum at Santa Elisabeth Hospital, Batam City.

The rupture of the amniotic membrane causes the opening of the intra-uterine connection with the extra uterine, so that microorganisms can easily enter and cause infection. Because the longer the latent phase, the higher the chances of intra-partum infection if the mother is frequently examined in, puerperal infection, peritonitis, sepsis, and causes asphyxia in the newborn.

According to Hacker (2001) the reduction in amniotic fluid in PROM delivery can cause cord compression which causes a slowing of the fetal heart rate so that the fetus experiences hypoxia and continues to become asphyxic.

This is in accordance with the theory that asphyxia neonatorum can be caused by flow disturbances in the umbilical cord, one of which is premature rupture of membranes (Manuaba, 1998: 319). If premature rupture of the membranes can cause compression of the umbilical cord, causing the fetus to be deficient in $\mathrm{O} 2$ and increased $\mathrm{CO} 2$ levels, then stimulation of the vaginal nerves will result, which causes the fetal heart sound to slow down. Lack of $\mathrm{O} 2$ also stimulates the intestines so that meconium is released as a sign that the fetus is in an asphyxia state. In addition, the amniotic fluid also functions to clean the birth canal and affect the condition in the vagina so that the baby is less infected, so that if there is premature rupture of membranes which increases infection in the uterus which causes respiratory problems in the fetus (Prawirohardjo, 2002: 75). symptoms of infection, but the fetus may already be infected, because intrauterine infection occurs before symptoms in the mother are felt so that it will increase perinatal mortality and morbidity (Mochtar, 1998: 257)

This study is in line with the research conducted by Wiradharma (2012) which found that there was a relationship between PROM and the incidence of asphyxia (bad APGAR). According to Wiradharma (2012) mothers who have PROM have an 8-fold risk of having a baby with asphyxia compared to mothers who do not have PROM. And the results of this study are in line with Komsiyati (2015) at Ambarawa Regional Hospital, which states that there is a relationship between PROM and the incidence of asphyxia (bad APGAR) and mothers who experience PROM have a 12.158 times greater risk compared to mothers without PROM. As well as the results of research by Fatkhiyah (2008) at RSUD dr. Soeselo Slawi, Tegal Regency, which stated that the relationship between KPD and the incidence of asphyxia (bad APGAR) and mothers who experienced KPD had a 3.481 times greater risk compared to mothers without PROM

Premature rupture of membranes can also cause premature labor, in preterm pregnancy the fetal organs are not functioning optimally, for example the lungs. Short-term complications in preterm babies are associated with the maturation of the fetal lungs which causes hypoxia so that the baby is asphyxic at the end.

\section{CONCLUSION}

Based on the results of research conducted at the Santa Elisabeth Hospital in Batam City, it can be concluded that:

1. More than half $(64.8 \%)$ of mothers do not experience PROM.

2. Most $(80.2 \%)$ neonates had no neonatal asphyxia.

3. There is a significant relationship $(p=0.004)$ between KPD and APGAR value at term delivery at Santa Elisabeth Hospital, Batam City

\section{SUGGESTION}

\section{For Health Agencies}

In this study, it can be used as a means of improving quality, service and reducing maternal and infant mortality 
and morbidity in the incidence of PROM.

2. For Educational Institutions

The results of this study are expected to be input, information, and to increase knowledge.

3. For further researchers

This can be done by adding other variables such as neonatal asphyxia, neonatal sepsis, anemia, parity, age, and others. And the sampling method used controls so that the results have a relationship between the incidence of PROM

\section{DAFTAR PUSTAKA}

Anjani, A. D., Aulia, D. L. N., \& Wibisono, C. (2018). INFORMATION GIVING EFFECT TO KNOWLEDGE MOTHERS WITH BABIES OF INFANT MASSAGE

Anjani, A. D. (2016). EFEKTIFITAS PEMBERIAN PENDIDIKAN KESEHATAN TERHADAP KECEMASAN PADA IBU PRIMIPARA DALAM MELAKUKAN PERAWATAN BAYI BARU LAHIR USIA 0-7 HARI. Jurnal Kebidanan Malahayati, 2(3)

Aulia, Devy Lestari Nurul. (2019). Pengaruh Pemberian Informasi Terhadap Pengetahuan Ibu Hamil Tentang Program Perencanaan Persalinan dan Pencegahan Komplikasi. Jurnal Kebidanan Malahayati. 5(1)

Betsy, dkk. 2013. Modul Manajemen Intrapartum. Jakarta: EGC.

Chapman, V. 2003. Asuhan Kebidanan, Persalinan dan Kelahiran. Jakarta: EGC.

Cunningham, F.G, dkk. 2012. Obstetri Williams, ed. 23, Vol. 1. Jakarta: EGC.

Dainty Maternity, S. S. T., Keb, M., \& Anjani, A. D. (2018). ASUHAN KEBIDANAN NEONATUS, BAYI, BALITA, DAN ANAK PRASEKOLAH. Penerbit Andi

Departemen Kesehatan Republik Indonesia. 2013. Fenomena Ketuban Pecah Dini. Jakarta: Departemen Kesehatan RI

$$
\text { 2008. Upaya }
$$

Percepatan Penurunan Angka Kematian Ibu. http://kesehatanibu.depkes.co.id (Diakses 16 Maret 2017).

Dinas Kesehatan Kota Batam. 2016. Profil Kesehatan Kota Batam Tahun 2015. Kota Batam.

Dorland, W. A. N. 2010. Kamus Kedokteran Dorland, ed. 31. Jakarta: EGC.
Fatkhiyah, N. 2008. Hubungan antara Persalinan Ketuban Pecah Dini dengan Kejadian Asfiksia Neonatorum di RSUD $d r$. Soeselo Kabupaten Tegal. Tegal: Sekolah Tinggi Ilmu Kesehatan Bhamada.

Firdhausya, R. 2015. Hubungan Status Paritas dengan Kejadian Ketuban Pecah Dini pada Ibu Bersalin di RSUD Panembahan Senopati Bantul. Yogyakarta: Sekolah Tinggi Ilmu Kesehatan 'Aisyiyah.

Hacker, N. F, dan Morce, J. D. 2001. Esensial Obstetri dan Ginekologi. Jakarta. Hipokrates.

Kementrian Kesehatan Republik Indonesia. 2014. Profil Kesehatan Indonesia 2014. Jakarta: Kementrian Kesehatan RI.

Komsiyati. 2015. Hubungan Kejadian Ketuban Pecah Dini dengan Kejadian Asfiksia pada Bayi Baru Lahir di RSUD Ambarawa tahun 2014. Semarang: Sekolah Tinggi Ilmu Kesehatan Ngudi Waluyo.

Leveno, K, dkk. 2009. Obstetri Williams, ed. 21. Jakarta: EGC.

Manoe, dkk. 2008. Gangguan Fungsi Multi Organ pada Bayi Asfiksia Berat. Jakarta: Universitas Indonesia.

Manuaba, I. B. G. 2007. Pengantar Kuliah Obstetri. Jakarta: EGC

2008. Gawat Darurat Obstetri Ginekologi dan Obstetri Ginekologi Sosial untuk Profesi Bidan. Jakarta: EGC.

Kebidanan, Penyakit Kandungan dan Keluarga Berencana untuk Pendidikan Bidan. Jakarta: EGC.

2012. Ketebalan Selaput Ketuban sebagai Faktor Risiko Persalinan Preterm. Denpasar: Universitas Udayana.

Maternity, Dainty; Ratna, DP; Devy, LNA. (2017). Asuhan Kebidanan KomunitasDisesuaikan dengan Rencana Pembelajaran Kebidanan. Penerbit Andi, Yogyakarta 
Morgan, G dan Hamilton, C. 2009. Obstetri dan Ginekologi, Praktik. Jakarta: EGC.

Norma, N, dkk. 2013. Asuhan Kebidanan Patologi. Yogyakarta: Nuha Medika.

Notoatmodjo, S. 2010. Metodologi Penelitian Kesehatan. Jakarta: Rineka Cipta.

Nugroho, T. 2010. Buku Ajar Obstetri Untuk Mahasiswa Kebidanan. Yogyakarta: Nuha Medika.

2012. Obstetri dan Ginekologi Kebidanan dan Keperawatan. Yogyakarta: Nuha Medika.

Oxorn, H dan Forte, W. R. 2003. Ilmu Kebidanan Patologi dan Fisiologi Persalinan Human Of Labor and Birth. Jakarta: Yayasan Essentia Medica

\section{Kebidanan: Patologi dan Fisiologi} Persalinan. Yogyakarta: Yayasan Essentia Medica

Prawirohardjo, S. 2010. Ilmu Kebidanan. Jakarta: P.T Bina Pustaka Sarwono Prawirohardjo.

$2013 . \quad$ Ilmu Kebidanan. Jakarta: P.T Bina Pustaka Sarwono Prawirohardjo.

Rahayu, A. 2009. Hubungan Antara Lama Ketuban Pecah Dini Terhadap Nilai APGAR Pada Kehamilan Aterm Di Badan Rumah Sakit Daerah Cepu. Surakarta: Universitas Muhammadiyah Surakarta.

Rumengan, J, dkk. 2015. Metodologi Penelitian Kuantitatif. Medan: Perdana Publishing

Saifudin, A. 2010. Ilmu Kebidanan. Jakarta: P.T Bina Pustaka Sarwono Prawirohardjo.

Sepduwiana, H. 2011. Faktor Terjadinya Ketuban Pecah Dini pada Ibu Bersalin di Rumah Sakit Umum Daerah Rokan Hulu. Riau: Universitas Pasir Pengaraian.

Setiawan, N. 2007. Penentuan Ukuran Sampel Memakai Rumus Slovin dan Tabel Krejcie-Morgan, Telaah Konsep dan Aplikasinya. Bandung: Universitas Padjadjaran.

Sujiyatini. 2011. Catatan Asuhan Ibu Nifas. Yogyakarta: Nuha Medika.
Susila dan Suyanto. 2015. Metodologi Penelitian Cross Sectional. Klaten Selatan: Bossscript.

Varney, H, dkk. 2004. Buku Ilmu Kebidanan. Jakarta: EGC

2007. Buku Ajar Asuhan Kebidanan, ed.4, Vol. 2. Jakarta: EGC.

Wiradharma. 2012. Risiko Asfiksia pada Ketuban Pecah Dini di RSUP Sanglah. Denpasar: Universitas Udayana. 